\title{
Open Innovation and CSR, Determinants in Logistics and Performance in Commercial SMES
}

\author{
Luis Enrique Valdez-Juárez ${ }^{1}$, Elva Alicia Ramos-Escobar ${ }^{1}$, Gonzalo Maldonado Gúzman ${ }^{2}$ \& José Alonso \\ Ruiz-Zamora ${ }^{1}$ \\ ${ }^{1}$ Faculty of economic and administrative sciences, Instituto Tecnológico de Sonora, Mexico \\ ${ }^{2}$ Faculty of Business Sciences, Autonomous University of Aguascalientes, Mexico \\ Correspondence: Luis Enrique Valdez-Juárez, Faculty of economic and administrative sciences, Obregon Sonora, \\ Mexico., 85000, Mexico.
}

Received: December 16, 2019

Accepted: January 8, 2020

Online Published: January 16, 2020

doi:10.5539/ibr.v13n2p50

URL: https://doi.org/10.5539/ibr.v13n2p50

\begin{abstract}
The purpose of this article is to examine the effects of open innovation and corporate environmental social responsibility on logistics and performance that is manifested in SMEs. The research is based on a sample of 101 companies located in the Guaymas Sonora region located in the Northwest of Mexico. The data collection was carried out in a period between September and November 2019, with the support of a structured self-directed survey of the company manager. For the analysis and validation of the results, the statistical technique of structural equation modeling (SEM) based on variance through PLS (Partial Least Square) has been used. The results indicate that open innovation and environmental corporate social responsibility have a significant influence on the logistics processes of SMEs, and that logistics is also a business practice that allows to increase Performance. The work contributes to the development of the literature and theory of dynamic capabilities and sustainability.
\end{abstract}

Keywords: Entrepreneurial Orientation (EO), Corporate Social Environmental Responsibility (CSER), Innovative Attitude (IA), Risk Taking (RT), Performance (PERF) Micro, Small and Medium Enterprises (MSMEs)

\section{Introduction}

Since the beginning of the last century, organizations have been in the constant struggle for competitiveness and permanence in the markets. Therefore, business owners have tried to incorporate new strategies that allow them to obtain more profitable organizational and financial results. One of the most common strategic actions is the incorporation of innovation in products (services) and / or internal processes of companies. In the literature there is a great diversity of the adoption and application of innovation, from the business point of view the majority has focused on the differentiation of products, processes and management systems that help give a competitive advantage ( technological and organizational innovation) (Abrahamson, 1991; van Oorschot, Hofman, \& Halman, 2018). There are authors like Crossan \& Apaydin (2010) and Drucker (2014) that see innovation as the production or adoption, assimilation and exploitation of a novelty that includes added value in new products, new production methods and management systems, which positively affect the economy of a society and which also influences the renewal and expansion of products, services and markets. Recently, innovation has taken a 360-degree turn due to what new theoretical currents have revealed that innovation moves from a completely closed systematic approach to an open and interactive landscape. Experts on the subject have stated that open innovation is visualized as internal and external knowledge with support in the new technologies that the company used for the production of its goods, services and processes (Chesbrough, 2006; West, Salter, Vanhaverbeke, \& Chesbrough, 2014). Other key factors in competitiveness have been corporate social responsibility (CSR), in all its dimensions (social, economic and environmental), however, companies are betting more on the application of environmental actions (Eikelenboom \& de Jong, 2019; Revell, Stokes, \& Chen, 2009). In recently developed models from a dynamic capacity theory perspective, these innovative strategies are focusing on sustained competitiveness for all organizations and more frequently within Small and Medium Enterprises (SMEs) (Teece, 2007, 2016). This theory of the dynamic capacities has been developed by Teece (2007) and reinforced by Andreeva \& Ritala (2016), have contemplated a series of higher level strategies that help companies to be more competitive and profitable over time. Among the main strategies are: open innovation (support in knowledge management and new technologies), 
CSR and logistics as a fundamental part of the supply chain of companies. To achieve a positive profitability and better organizational results, it is necessary to integrate, reconstruct and reconfigure all these internal and external competences to face the constant changes in the global markets (Aagaard, 2016; Andreeva \& Ritala, 2016). Despite the broad benefits offered by these new business models based on open innovation practices and sustainability, SMEs face a lot of problems and obstacles that have prevented them from skipping these fences. Some of these barriers are: 1) the poor strategic vision of managers and investors (Kim \& Mauborgne, 2018; Teece, 2010), 2) little investment in the development of creativity of human capital, 3) there is no budget for Research and Development (R\&D) (Cakar \& Erturk, 2010; Chesbrough, 2006), 4) high government regulation on CSR (environmental processes), 5) little importance in benchmarking (Naranjo-Valencia, Jiménez-Jiménez, \& Sanz-Valle, 2011), 6) high production costs with slender certification-based processes (Granly \& Welo, 2014; L. Valdez-Juárez et al., 2018), 7) little employee environmental commitment (Hatala, 2005; Nonaka \& Toyama, 2003), and 8) high unfair competition from companies with unreliable products and brands (De, Chowdhury, Dey, \& Ghosh, 2018; Laudal, 2011; Nawaser, Khaksar, \& Shakhsian, 2011; Robinson, 2006). In the theoretical and empirical review, it has been detected that there are a large number of studies that focus on the analysis of the adoption and behavior of new business models on the results of open innovation oriented towards sustainability of the processes of large organizations (McCormick \& Kautto, 2013; Teece, 2010), however few focus on the context of SMEs (Anderson, Acur, \& Corney, 2018; West et al., 2014). The research work aims to: 1. Analyze the effects it has on Open Innovation on Logistics, Environmental CSR and Performance, 2. Verify the influence of Environmental CSR on Logistics and Performance, and 3. Examine the effect that Logistics has on Performance that is generated in commercial SMEs in the Guaymas Sonora region in Mexico.

\section{Review of the Literature and Hypothesis Development}

The study of open innovation has been in the last decade a topic quite addressed by researchers in the area of business sciences due to its importance and the different benefits it brings to different organizations including family and non-family SMEs (Ali, Zwetsloot, \& Nada, 2019; Ardito, Messeni Petruzzelli, Dezi, \& Castellano, 2018; Chrisman \& Patel, 2012). Studies have generally related to open innovation as a dynamic capacity of business knowledge that contributes to organizational growth and development, mainly in improving profitability and productivity (Del Vecchio, Secundo, Rubino, Garzoni, \& Vrontis, 2019; Ferraris, Giachino, Ciampi, \& Couturier, 2019; Saunila, 2019). In addition, the incursion of the interaction that has open innovation with corporate social responsibility has recently increased as a key factor for organizational learning systems which lead to maturity in the logistic and productive processes that are related to sustainability (McCormick \& Kautto, 2013b; Scuotto, Del Giudice, Bresciani, \& Meissner, 2017; Vitolla, Rubino, \& Garzoni, 2016, 2017). Although these two business strategies have been key elements to increase competitiveness in companies preferably located geographically in areas with high economic potential and social development (Teece, 2016; West et al., 2014), in the Latin American region there are few regions where they have been considered as engines key to development and economic growth, however, countries such as Brazil, Chile and Mexico have been incorporating initiatives in their public policies so that companies incorporate and strengthen their innovation practices and business sustainability actions (GID, 2018; Maldonado-Guzmán, Garza-Reyes, Pinzón-Castro, \& Kumar, 2017; OECD, 2017; Valdez-Juárez, Solano-Rodríguez, \& Philippe-Martin, 2018).

\subsection{Open Innovation, Its Effect on CSR, Logistics and Performance}

In the theoretical and empirical context, open innovation is interpreted as a differentiating strategy that generates sustained competitiveness for organizations (West et al., 2014). In the study of the relationship between open innovation and Environmental CSR, it has been found that this connection really exists (Silvestre \& Țîrcă, 2019), however, some experts in the field have explained that these two strategic activities have a two-way relationship (Bocquet, Le Bas, Mothe, \& Poussing, 2019; Näyhä, 2019; Wikhamn \& Styhre, 2017). Recent studies have shown that products and services developed with internal and external knowledge from open innovation, generate a great deal of benefits for the interest groups of companies, including ecological products, more durable and less deceptive products (not imitations), actions that positively impact the reputation and profits of companies (Ramaanuni \& Mukherjee, 2014). From the previous context the following hypothetical approach has been generated:

\section{H1. The greater open innovation practices, the greater environmental responsibility in SMEs}

In addition, innovative businesses are incorporating lean methodologies and processes from other organizations in order to improve some logistics activities, among the main actions are the selection of suppliers with ecological practices and reasonable purchases of materials and supplies for lean processes, with this the delivery in time of the products demanded by the clients is achieved (Diouf \& Kwak, 2018; Gupta \& Barua, 2017). These 
actions are changing companies in businesses with green and / or ecological logistics systems, allowing their interest groups (partners, customers and suppliers) to be satisfied more convincingly, but also turning businesses into an environmentally responsible conscience (Melander, 2017; Multaharju, Lintukangas, Hallikas, \& Kähkönen, 2017). From the theoretical and empirical review the following hypothesis has been developed: H2. The greater open innovation practices, the greater improve in the logistics processes of SMEs.

Traditionally, businesses have obtained economic and financial benefits from the good practices they develop in the interior, however, with the adoption and dissemination of open innovation, companies are experiencing exponential and sustainable profitability results (Tucci, Chesbrough, Piller, \& West, 2016). Recent studies have shown that the combination of internal and external knowledge that companies capture and exploit is leading them towards more significant profitability results (Chesbrough, 2006; S. K. Singh, Gupta, Busso, \& Kamboj, 2019). These changes are transforming human capital into intellectual capital (inventions-patents) and are generating more valuable products and creating collaborative networks abroad, same actions that are enhancing the competitiveness, performance and financial profitability of the SMEs (Agostini \& Nosella, 2017; Scuotto et al., 2017). From the theoretical and empirical review the following hypothesis has been developed: H3. The greater practices of open innovation, the greater the increase performance in SMEs.

\subsection{Environmental Corporate Social Responsibility, Its Relationship with Logistics and Profitability in Companies}

The CSR is a strategy that most organizations are adopting independently of the sector and / or the productive activity they are developing. In addition, since the explosion of the industrial revolution, the arrival of the knowledge economy and the enormous advance of new technologies, organizations are incorporating these practices into logistics processes (Jia, Zuluaga-Cardona, Bailey, \& Rueda, 2018; McWilliams, Parhankangas, Coupet, Welch, \& Barnum, 2016). Some of the methods and / or processes that have revolutionized the delivery of value to interest groups have been improvements in logistics as an essential part of the supply chain for companies, which plays a decisive role in satisfaction of clients and in returns for investors (Sodhi \& Tang, 2018; Wolf, 2014). The theory of sustainability has argued and exposed that the companies that have a better performance and that deliver greater value to the stakeholders are the companies called green (Mebratu, 1998; Rajeev, Pati, Padhi, \& Govindan, 2017; Spence, 2016). In the context of SMEs, recent studies have corroborated that this type of organizations are adopting sustainable practices for their production processes, in the selection of their suppliers, reasonable (ecological) purchases, waste management, in the service process, in the marketing of its products and implementing reverse logistics actions, with the firm purpose of fully satisfying its customers (Jia et al., 2018; Quarshie, Salmi, \& Leuschner, 2016; L. Valdez-Juárez et al., 2018). In addition, these actions are leading SMEs to place themselves in new markets and are reaching more demanding consumers (Dey et al., 2018; Zhao, Meng, He, $\& \mathrm{Gu}, 2019)$. Responsible practices focused on the sustainability of the processes in which logistics intervene under the ecological practices of business have achieved a great amount of organizational and financial benefits. Some authors in their recent research have concluded that environmental social responsibility in conjunction with sustainable logistics has allowed to improve products, improve the quality of the service that the client receives, has reduced waste in the processes and has managed to take care of its resources such as electricity and water, thereby reducing its costs and increasing its economic profitability (Dey et al., 2018; Jayanti \& Rajeev Gowda, 2014; Multaharju et al., 2017). From the theoretical and empirical review, we emit the following hypothesis: H4. Logistics positively influences the increase in Performance in the SMEs. H5. Environmental Corporate Social Responsibility influences the Logistics that exist in the SMEs. H6. Environmental Corporate Social Responsibility influences the increase in Performance in the SMEs. 


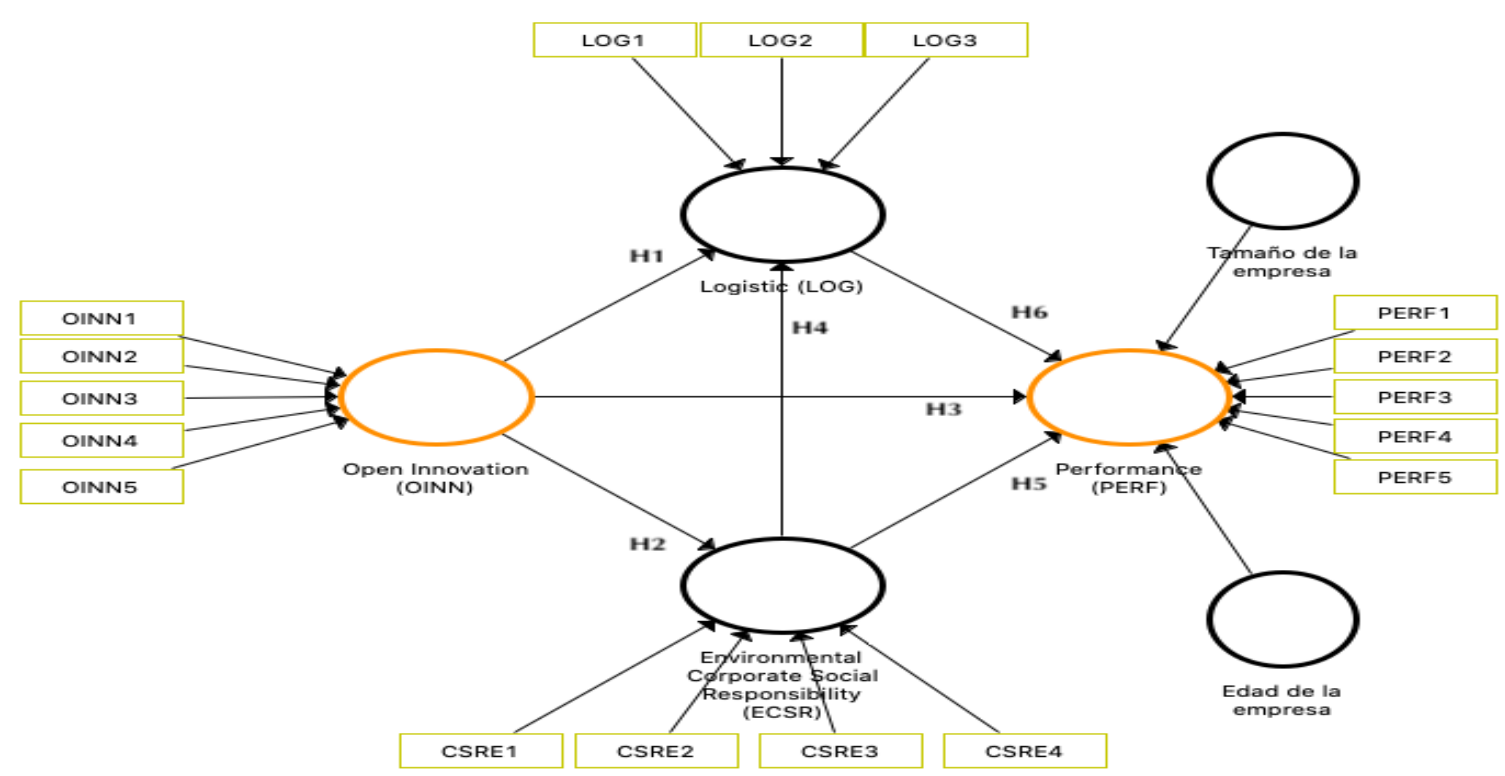

Figure 1. Theoretical model

Note. Figure 1 shows the 6 structured hypotheses in the proposed theoretical model.

\section{Methodology}

The study is predictive quantitative and based on the principles of stratified sampling for finite populations. The population is formed of commercial SMEs established in the city of Guaymas Sonora in Northwestern Mexico and has been segmented according to the activity criteria. The number of companies (population) in the metropolitan region of Guaymas is 278 companies in the commercial sector, these data have been obtained from the information of the economic census provided by the National Statistical Directory of Economic Units (DENUE) of the National Institute of Statistics and Geography (INEGI, 2019). The sample size was determined to ensure that the maximum margin of error for the estimation of a proportion (relative frequency of response in a specific item of a question) was less than 0.03 points with a $95 \%$ confidence level. The technique for collecting the information was through a personal interview (questionnaire) addressed to the owner and/or manager of the SME. The field work was carried out during the months of September to November of the year 2019. Finally, a sample of 101 surveys was obtained.

\subsection{Measurement of the Variables}

Open Innovation (OINN). For the analysis and statistical validation, this construct was measured in a first-order one-dimensional form of formative type in mode B. For its theoretical and empirical measurement, its relationship with the sustainability practices in companies was considered. The studies of Chesbrough (2006) and West et al. (2014), have been taken as a reference to develop the measurement scales of this construct. For this purpose, 5 questions were structured in the questionnaire and were provided to the SME manager to give their opinion about the importance for the company of open innovation practices in the last two years. The answer options of the questionnaire are based on a Likert-type scale of 5 points with $1=$ Unimportant and $5=$ Very Important. All questions comply with the internal consistency and validity indicators, (see table 2).

Environmental Social Responsibility (ECSR). This construct was measured in one-dimensional form of formative type in B mode. Based on the theoretical review carried out, focused on sustainability, this variable was measured taking as reference the studies developed by Mebratu (1998), McWilliams et al. (2016) and, of the study proposed by Jia et al. (2018). The variable has been measured with 4 questions formulated in a questionnaire addressed to the managers of SMEs to issue their answers related to the sustainable practices they develop inside and outside the company in the last two years. For this, a 5-point Likert scale has been used with 1 $=$ total disagreement and $5=$ total disagreement. All questions comply with the internal consistency and validity indicators (see table 2).

Logistics (LOG). Based on the current theories focused on sustainability and sustainable practices, a review of the literature has been carried out to define the measurement of this construct taking as reference the studies developed by Halley \& Guilhon (1997) and by Chan, Qi, Chan, Lau, \& Ip (2003). This variable was measured 
with 3 questions using a Likert type scale of 5 points, with $1=$ Slight importance and $5=$ Very important. The questions were structured in a questionnaire addressed to the SME manager so that they could give their perception about the degree of importance of the logistic processes that the company has carried out in the last two years. All questions comply with the internal consistency and validity indicators (See table 2).

Performance (PERF). This construct was measured in one-dimensional form of formative type in B mode. To develop the measurement scales for this variable, the studies developed by Quinn \& Rohrbaugh (2011) and by Singh, Olugu, Musa, \& Mahat (2018) were taken as a reference. This variable was measured with 5 questions using a self-directed survey of the SME manager to issue their responses about Performance behavior in the last two years. A 5-point Likert scale was used for its measurement, with $1=$ Total disagreement and $5=$ Strongly agree. All questions comply with the internal consistency and validity indicators (see table 2).

\section{Results}

\subsection{Measure Model}

The measurement of the formative type variables does not need to be correlated and it is assumed that they are free of error, the traditional evaluation through the reliability and validity indicators is considered not necessary for this type of constructs (Bagozzi, Yi, \& Phillips, 1991). At the construct level the validation has been carried out through the validity of content (theoretical) and with the analysis of the discriminant validity (if the correlations are below the value of 0.7, the presence of discriminant exists) (Urbach \& Ahlemann, 2010), see Table 1.

Table 1. Discriminant validity

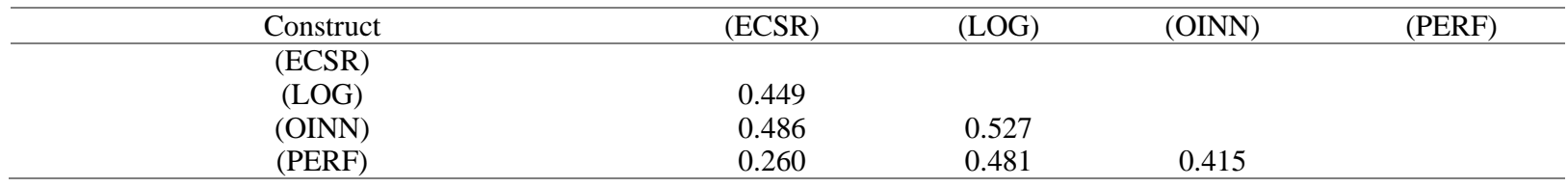

Note. Table 1 shows that the values of the correlations between the constructs are below the value of 0.7. Environmental Corporate Social Responsibility (ECSR), Logistic (LOG), Open Innovation (OINN), Performance (PERF).

Regarding the indicator level, the variables were evaluated through the bootstrapping process using a two-tailed Student's t-distribution. The indicators that have been considered to perform this test are: the level of potential multicollinearity between the indicators, the inflation factor of the variance (VIF) (less than 3.3) (Diamantopoulos \& Siguaw, 2006), the valuation of the pesos and their P value (at least $95 \%$ of significance) (Hair, Jr. , Marko Sarstedt, Christian M. Ringle, 2017), see Table 2.

Table 2. Internal consistency of the constructs

\begin{tabular}{|c|c|c|c|c|}
\hline Constructs & VIF & Loads & Standard deviation & t value \\
\hline \multicolumn{5}{|l|}{ Open Innovation } \\
\hline OINN1 & 1.255 & $0.151 * *$ & 0.270 & 0.558 \\
\hline OINN2 & 1.153 & $0.560 * * *$ & 0.191 & 2.939 \\
\hline OINN3 & 1.911 & $0.256 * * *$ & 0.245 & 1.043 \\
\hline OINN4 & 1.850 & $0.147 * *$ & 0.216 & 0.680 \\
\hline OINN5 & 1.392 & $0.329 * * *$ & 0.247 & 1.332 \\
\hline \multicolumn{5}{|l|}{ CSR Environmental } \\
\hline ECSR1 & 1.101 & $0.572 * * *$ & 0.281 & 2.038 \\
\hline ECSR2 & 1.402 & $0.399 * * *$ & 0.258 & 1.546 \\
\hline ECSR3 & 1.453 & $0.161 * *$ & 0.239 & 0.675 \\
\hline ECSR4 & 1.483 & $0.296 * * *$ & 0.269 & 1.097 \\
\hline \multicolumn{5}{|l|}{ Logistics } \\
\hline LOG1 & 1.030 & $0.276^{* * *}$ & 0.222 & 1.244 \\
\hline LOG2 & 1.074 & $0.461 * * *$ & 0.341 & 1.352 \\
\hline LOG3 & 1.044 & $0.717 * * *$ & 0.261 & 2.750 \\
\hline \multicolumn{5}{|l|}{ Performance } \\
\hline PERF1 & 1.098 & $0.188 * *$ & 0.208 & 0.903 \\
\hline PERF2 & 1.065 & $0.542 * * *$ & 0.297 & 1.824 \\
\hline PERF3 & 1.114 & $0.341 * * *$ & 0.258 & 1.320 \\
\hline PERF4 & 1.121 & $0.489 * * *$ & 0.269 & 1.821 \\
\hline PERF5 & 1.042 & $0.150 * *$ & 0.275 & 0.544 \\
\hline
\end{tabular}

Note. Table 2 shows the results of the analysis of the value of the VIF, the weights, the standard deviation and the value of T Student. 


\subsection{Structural Model}

The statistical technique of structural equations based on variance was used to validate and / or verify the hypotheses raised in this investigation through SmartPLS version 3.2.8 Professional. The use of this technique with the support of this software is appropriate in predictive, exploratory and confirmatory research (Henseler, Hubona, \& Ray, 2016). Table 3 shows the results of the $\beta$ coefficient, the degree of significance ( $p$ value), the importance of the distribution of the values using Student's $t$ and standard deviation. To test the hypothesis, the bootstrapping procedure was used with 5,000 sub-samples as recommended Chin (1998).

Table 3. Hypothesis test results

\begin{tabular}{llllllll}
\hline \multicolumn{1}{c}{ Hypothesis } & Beta coefficient & Standard deviation & t statistics & P Values & F Squared & $\begin{array}{c}\text { Explained } \\
\text { Variance }\end{array}$ & \multicolumn{1}{c}{ Result } \\
\hline H1. INNA -> LOG & $0.404^{* * *}$ & 0.128 & 3.147 & 0.001 & 0.185 & $21.29 \%$ & Confirmed \\
H2. INNA -> RSCA & $0.486^{* * *}$ & 0.071 & 6.807 & 0.000 & 0.310 & $23.62 \%$ & Confirmed \\
H3. INNA -> PERF & 0.210 & 0.201 & 1.046 & 0.148 & 0.055 & $8.72 \%$ & Rejected \\
H4. RSCA -> LOG & $0.252^{*}$ & 0.158 & 1.598 & 0.055 & 0.072 & $11.31 \%$ & Confirmed \\
H5. RSCA -> PERF & 0.008 & 0.163 & 0.050 & 0.480 & 0.006 & $0.00 \%$ & Rejected \\
H6. LOG -> PERF & $0.330^{*}$ & 0.238 & 1.386 & 0.083 & 0.005 & $8.58 \%$ & Confirmed \\
\hline
\end{tabular}

Note. The table shows the results of the hypotheses (beta value), the $t$ value, the standard deviation and the effect size of the predictive model through the test of $\mathrm{F}^{2}$, in addition, the levels of significance are shown according to the values of: $*, * *, * * *, 10 \%$ to $5 \%$ and $1 \%$ respectively.

Table 3 shows the results of the hypotheses tested in the analysis model that was performed with the system of structural equations through Partial Least Square (PLS). We find empirical support for the structured hypotheses in the model (H1, H2, H4 and H6). The hypothesis results show positive and significant effects at $99 \%$ and $90 \%$. Additionally, two variables of control of the age of the company and the size of the company have been introduced to the proposed model. The results indicate that the age of the company has a significant influence on the performance in the SME according to the values of $(\beta=0.200 * *)$, contrary to the age of the company according to the value of $(\beta=0.013)$ respectively.

To evaluate the adjustment of the proposed model with SEM techniques that are based on variance through PLS, we consider: 1) the value of the trajectory coefficients, 2$)$ the analysis of $\left(\mathrm{R}^{2}\right)$ and 3$)$ the values of $\left(\mathrm{F}^{2}\right)$ which are significant individual measures to explain the predictability of the structural model (Chin \& Dibbern, 2010). Our strongest model coefficients are from $0.486^{* * *}, 402 * * *, 0.330 *$ and $0.252 *$. For the analysis of the prediction quality of the model, the values of $\left(\mathrm{R}^{2}\right)$, have been analyzed, the results 0.312 of the Logistics variable, 0.229 for the RSCA variable and 0.271 of the Performance show a strong effect with approximate values of 0.25 and very close to the value of 0.36 as recommended (Hair, Jr., Sarstedt, \& Ringle, 2017). The value $\left(F^{2}\right)$ is measured according to the values of $0.02,0.15$ and 0.35 these indicate weak, medium or large effect (Ringle, Wende, \& Becker, 2017). The analysis of $\mathrm{F}^{2}$, shows the results of the key relationships of the model with values of 0.310 , $0.185,0.072$ and 0.055 . The statistical test $\mathrm{Q}^{2}$ (cross-validated redundancy index) is used to evaluate and test the predictive relevance of endogenous constructs in a model. The model was evaluated through the blindfolding technique (Ringle et al., 2017). Our values are 0.102 for the LOG, 0.090 for the RSCA and 0.058 for the PERF. Values greater than (0) show a remarkable predictive quality, thereby demonstrating the existence of a remarkable explanatory quality of the model (Chin, 1998; Hair, Hult, Ringle, Sarstedt, \& Thiele, 2017). To explain more accurately the predictive effect, we have added a goodness of fit test. When the standardized value of the residual quadratic mean (SRMR) is in a range $(<0.08-0.1)$, there is an acceptable adjustment (Schuberth, Henseler, \& Dijkstra, 2018). Our result of 0.080 confirms that the proposed model has an acceptable predictive quality and that the empirical results are consistent with the theory.

\section{Discussion and Conclusion}

In the context of SMEs under a cataloged economy in development and with internal and external political difficulties, in this section the main conclusions and discussions of the results of the study are issued. Our arguments are with a perspective based on the theory of dynamic capabilities and the theory of sustainability. The result is more strongly focused on $\mathrm{H} 2$, this relationship is given by open innovation and corporate social environmental responsibility. In this same direction, we find that $\mathrm{H} 1$ has a strong effect on logistics processes in SMEs. These findings allow us to state that organizations with innovative capabilities that collect information and knowledge from both the interior (management advice, employee experience, repositories information and training) and from abroad (training, consultant advice, support from universities and research centers), they are exploiting it to the fullest and they are also using their resources in ecological actions within their logistics processes (Brink, 2018; Teece, 2010, 2016). These higher-level strategies make them companies with sustainable 
and increasingly competitive business approaches and models (Mention, 2011; Mishra, 2017; West et al., 2014). These findings are aligned with the theory of Dynamic Capabilities, with the theory of Sustainability and with most of the empirical studies analyzed (Andreeva \& Ritala, 2016; Carter \& Rogers, 2008a; Hahn \& Kühnen, 2013; Teece, 2007). In this same aspect, but with a force of lesser magnitude, we find that the H4 shows that the RSCA has a significant effect on the logistics processes of the SME. These results obey and are related to the innovative and sustainable practices that are being carried out by this type of companies, which are focused on the adoption of ecological actions, saving of consumables, reasonable selection of suppliers and the conscientious purchases that lead finished. In addition, these types of companies are increasingly aware of the maximization of benefits through the reduction of costs such as energy and other inputs used in their logistics processes. These findings have presented a very similar behavior with the theory of Dynamic Capabilities and Sustainability (Ahi \& Searcy, 2013; Andreeva \& Ritala, 2016; Carter \& Rogers, 2008b; McWilliams et al., 2016). Another significant result and with similar strength to the previous hypothesis was the H6, which represents the effect that Logistics has on the Performance of the SME. These findings inform us that these types of companies are obtaining some financial results, but not enough, this may be caused by good practices based on sustainable logistics processes, results that align with the theory of sustainability and empirical studies focused on sustainable and / or green businesses (Hannes, Christian, Christoph, \& Michael, 2014; Kalmykova, Sadagopan, \& Rosado, 2018; Multaharju et al., 2017). However, we do not find empirical support for H3 and H5, this leads us to infer that open innovation and Environmental CSR directly are not having a significant effect on Performance. Although SMEs are adopting new business models and leveraging their resources and taking their capabilities to a higher level such as open innovation and environmental actions, they are not benefiting significantly from this type of strategies (Anderson et al., 2018; Teece, 2007, 2010). The study has generated some implications that allow SMEs to visualize their path to sustained competitiveness: 1) it is important that SME managers continue to adopt new business models focused on sustainability practices and green logistics processes (Melander, 2017; Teece, 2010), 2) business owners should bet on the certification of their processes in matters of sustainability and CSR, such as the adoption of ISO 14000 and 26000 (Granly \& Welo, 2014; Moratis \& Cochius, 2017), 3) it is convenient that the managers of SMEs build a department focused on research, development and innovation $(\mathrm{R}+\mathrm{D}+\mathrm{I})$, 4) the practices of open innovation that are developed in the SME, should be focused and directed towards internal processes, improvement of products and services in order to obtain greater customer satisfaction results, greater sales and increased profits (Usman \& Vanhaverbeke, 2017; West et al., 2014), and 5) it is recommended that SMEs, perform benchmarking with greater intensity and form strategic alliances with higher level companies and with other institutions of technological, financial and innovation support (Carayannis, Barth, \& Campbell, 2012; Carayannis \& Samanta Roy, 2000). Some of the limitations generated in the investigation are: 1) the responses of managers are subjective opinions and may incur bias and / or convenience, 2) measurement scales were constructed and measured in a one-dimensional way, in the future they can be considered in multidimensional form, and 3) the statistical technique used was based on variance, in future analyzes statistical analyzes that focus on covariance can be considered. Finally, given the importance of open innovation and the issue of sustainability in the context of SMEs, it is convenient to continue with the analysis of the behavior of these variables and, at the same time, incorporate new variables that help strengthen future research. Some variables that can be contemplated are circular economy and bio economy.

\section{References}

Aagaard, A. (2016). Sustainable Business. River Publishers. Retrieved from https://books.google.com.mx/books?id=ExvkDAAAQBAJ

Abrahamson, E. (1991). Managerial Fads and Fashions: The Diffusion and Rejection of Innovations. Academy of Management Review, 16(3), 586-612. https://doi.org/10.5465/amr.1991.4279484

Agostini, L., \& Nosella, A. (2017). Enhancing radical innovation performance through intellectual capital components. Journal of Intellectual Capital, 18(4), 789-806. https://doi.org/10.1108/JIC-10-2016-0103

Ahi, P., \& Searcy, C. (2013). A comparative literature analysis of definitions for green and sustainable supply chain management. Journal of Cleaner Production, 52, 329-341. https://doi.org/10.1016/j.jclepro.2013.02.018

Ali, Z., Zwetsloot, I. M., \& Nada, N. (2019). An empirical study to explore the interplay of Managerial and Operational capabilities to infuse organizational innovation in SMEs. Procedia Computer Science, 158, 260-269. https://doi.org/10.1016/j.procs.2019.09.050

Anderson, R. W., Acur, N., \& Corney, J. (2018). How do SMEs Use Open Innovation When Developing New Business Models? In Researching Open Innovation in SMEs (pp. 179-209). WORLD SCIENTIFIC. 
https://doi.org/10.1142/9789813230972_0006

Andreeva, T., \& Ritala, P. (2016). What are the sources of capability dynamism? Reconceptualizing dynamic capabilities from the perspective of organizational change. Baltic Journal of Management, 11(3), 238-259. https://doi.org/10.1108/BJM-02-2015-0049

Ardito, L., Messeni Petruzzelli, A., Dezi, L., \& Castellano, S. (2018). The influence of inbound open innovation on ambidexterity performance: Does it pay to source knowledge from supply chain stakeholders? Journal of Business Research. https://doi.org/10.1016/j.jbusres.2018.12.043

Bagozzi, R. P., Yi, Y., \& Phillips, L. W. (1991). Assessing Construct Validity in Organizational Research. Administrative Science Quarterly, 36(3), 421. https://doi.org/10.2307/2393203

Bocquet, R., Le Bas, C., Mothe, C., \& Poussing, N. (2019). Strategic CSR for innovation in SMEs: Does diversity matter? Long Range Planning, 52(6). https://doi.org/10.1016/j.lrp.2019.101913

Brink, T. (2018). Organising of dynamic proximities enables robustness, innovation and growth: The longitudinal case of small and medium-sized enterprises (SMEs) in food producing firm networks. Industrial Marketing Management. https://doi.org/10.1016/J.INDMARMAN.2018.04.005

Cakar, N. D., \& Erturk, A. (2010). Comparing Innovation Capability of Small and Medium-Sized Enterprises : Examining the Effects of Organizational Culture. Journal of Small Business Management, 48(3), 325-359.

Carayannis, E. G., Barth, T. D., \& Campbell, D. F. (2012). The Quintuple Helix innovation model: global warming as a challenge and driver for innovation. Journal of Innovation and Entrepreneurship, 1(1), 2. https://doi.org/10.1186/2192-5372-1-2

Carayannis, E. G., \& Samanta Roy, R. I. (2000). Davids vs Goliaths in the small satellite industry:: the role of technological innovation dynamics in firm competitiveness. Technovation, 20(6), 287-297. https://doi.org/10.1016/S0166-4972(99)00137-6

Carter, C. R., \& Rogers, D. S. (2008a). A framework of sustainable supply chain management: moving toward new theory. International Journal of Physical Distribution \& Logistics Management, 38(5), 360-387. https://doi.org/10.1108/09600030810882816

Carter, C. R., \& Rogers, D. S. (2008b). A framework of sustainable supply chain management: moving toward new theory. International Journal of Physical Distribution \& Logistics Management, 38(5), 360-387. https://doi.org/10.1108/09600030810882816

Chan, F. T. S., Qi, H. J., Chan, H. K., Lau, H. C. W., \& Ip, R. W. L. (2003). A conceptual model of performance measurement for supply chains. Management Decision, 41(7), 635-642. https://doi.org/10.1108/00251740310495568

Chesbrough, H. W. (2006). Open Innovation: The New Imperative for Creating and Profiting from Technology. Harvard Business School Press. Retrieved from https://books.google.com.mx/books?id=OeLIH89YiMcC

Chin, W. W. (1998). Issues and Opinion on Structural Equation Modeling. MIS Quarterly, 22(1), 1.

Chin, W. W., \& Dibbern, J. (2010). Handbook of Partial Least Squares. Handbook of Partial Least Squares. https://doi.org/10.1007/978-3-540-32827-8

Chrisman, J. J., \& Patel, P. C. (2012). Variations in R\&D investments of family and nonfamily firms: Behavioral agency and myopic loss aversion perspectives. Academy of Management Journal. https://doi.org/10.5465/amj.2011.0211

Crossan, M. M., \& Apaydin, M. (2010). A Multi-Dimensional Framework of Organizational Innovation: A Systematic Review of the Literature. Journal of Management Studies, 47(6), 1154-1191. https://doi.org/10.1111/j.1467-6486.2009.00880.x

De, D., Chowdhury, S., Dey, P. K., \& Ghosh, S. K. (2018). Impact of Lean and Sustainability Oriented Innovation on Sustainability Performance of Small and Medium Sized Enterprises: A Data Envelopment Analysis-based framework. International Journal of Production Economics. https://doi.org/10.1016/J.IJPE.2018.07.003

Del Vecchio, P., Secundo, G., Rubino, M., Garzoni, A., \& Vrontis, D. (2019). Open innovation in family firms: empirical evidence about internal and external knowledge flows. Business Process Management Journal. https://doi.org/10.1108/BPMJ-03-2019-0142

Dey, P. K., Petridis, N. E., Petridis, K., Malesios, C., Nixon, J. D., \& Ghosh, S. K. (2018). Environmental 
management and corporate social responsibility practices of small and medium-sized enterprises. Journal of Cleaner Production, 195, 687-702. https://doi.org/10.1016/J.JCLEPRO.2018.05.201

Diamantopoulos, A., \& Siguaw, J. A. (2006). Formative versus reflective indicators in organizational measure development: A comparison and empirical illustration. British Journal of Management, 17(4), 263-282. https://doi.org/10.1111/j.1467-8551.2006.00500.x

Diouf, M., \& Kwak, C. (2018). Fuzzy AHP, DEA, and Managerial Analysis for Supplier Selection and Development; From the Perspective of Open Innovation. Sustainability, 10(10), 3779. https://doi.org/10.3390/su10103779

Drucker, P. (2014). Innovation and entrepreneurship: practice and principles. Retrieved from https://books.google.com.mx/books?id=NyqDBAAAQBAJ\&dq=entrepreneur+concepts, + Drucker+\&lr=\&h $\mathrm{l}=\mathrm{es} \&$ source $=$ gbs_navlinks_s

Eikelenboom, M., \& de Jong, G. (2019). The impact of dynamic capabilities on the sustainability performance of SMEs. Journal of Cleaner Production, 235, 1360-1370. https://doi.org/10.1016/J.JCLEPRO.2019.07.013

Ferraris, A., Giachino, C., Ciampi, F., \& Couturier, J. (2019). R\&D internationalization in medium-sized firms: The moderating role of knowledge management in enhancing innovation performances. Journal of Business Research. https://doi.org/10.1016/j.jbusres.2019.11.003

Forkmann, S., Henneberg, S. C., Naudé, P., \& Mitrega, M. (2016). Supplier relationship management capability: a qualification and extension. Industrial Marketing Management, 57, 185-200. https://doi.org/10.1016/J.INDMARMAN.2016.02.003

GID. (2018). Global Innovation Index. Energizing the World with Innovation. Retrieved February 25, 2019, from https://www.globalinnovationindex.org/gii-2018-report

Granly, B. M., \& Welo, T. (2014). EMS and sustainability: experiences with ISO 14001 and Eco-Lighthouse in Norwegian metal processing SMEs. Journal of Cleaner Production, 64, 194-204. https://doi.org/10.1016/J.JCLEPRO.2013.08.007

Gupta, H., \& Barua, M. K. (2017). Supplier selection among SMEs on the basis of their green innovation ability using BWM and fuzzy TOPSIS. Journal of Cleaner Production, 152, 242-258. https://doi.org/10.1016/j.jclepro.2017.03.125

Hahn, R., \& Kühnen, M. (2013). Determinants of sustainability reporting: A review of results, trends, theory, and opportunities in an expanding field of research. Journal of Cleaner Production, 59, 5-21. https://doi.org/10.1016/j.jclepro.2013.07.005

Hair, J. F., Hult, G. T. M., Ringle, C. M., Sarstedt, M., \& Thiele, K. O. (2017). Mirror, mirror on the wall: a comparative evaluation of composite-based structural equation modeling methods. Journal of the Academy of Marketing Science, 45(5), 616-632. https://doi.org/10.1007/s11747-017-0517-x

Halley, A., \& Guilhon, A. (1997, November 1). Logistics behaviour of small enterprises: Performance, strategy and definition. International Journal of Physical Distribution \& Logistics Management. https://doi.org/10.1108/09600039710182644

Hannes, H., Christian, B., Christoph, B., \& Michael, H. (2014). Sustainability-Related Supply Chain Risks: Conceptualization and Management. Business Strategy and the Environment, 23(3), 160-172. https://doi.org/10.1002/bse.1778

Hatala, J. P. (2005). Identifying Barriers to Self Employment: The Development and Validation of the Barriers to Entrepreneurship Success Tool. Performance Improvement, 18(4), 50-70. https://doi.org/10.1111/j.1937-8327.2005.tb00350.x

Henseler, J., Hubona, G., \& Ray, P. A. (2016). Using PLS path modeling in new technology research: updated guidelines. Industrial Management \& Data Systems, 116(1), 2-20.

https://doi.org/10.1108/IMDS-09-2015-0382

INEGI. (2018). Economic Census, summary of the final results. Mexico. Retrieved from http://internet.contenidos.inegi.org.mx/contenidos/productos/prod_serv/contenidos/espanol/bvinegi/product os/nueva_estruc/promo/frrdf_ce2014.pdf

Jayanti, R. K., \& Rajeev, G. M. V. (2014). Sustainability dilemmas in emerging economies. IIMB Management Review, 26(2), 130-142. https://doi.org/10.1016/j.iimb.2014.03.004 
Jia, F., Zuluaga-Cardona, L., Bailey, A., \& Rueda, X. (2018). Sustainable supply chain management in developing countries: An analysis of the literature. Journal of Cleaner Production, 189, 263-278. https://doi.org/10.1016/j.jclepro.2018.03.248

Joseph, F., Hair, J., Marko, S., Christian, M., \& Ringle, S. P. G. (2017). Advanced Issues in Partial Least Squares Structural Equation Modeling - Joseph F. Hair, Jr., Marko Sarstedt, Christian M. Ringle, Siegfried P. Gudergan - Google Libros. (SAGE, Ed.). Retrieved from

https://books.google.com.mx/books?id=-f1rDgAAQBAJ\&dq=CM+Ringle,+Wende,+2018+using+of+SEM + Smartpls $+\& l r=\& h l=e s \&$ source $=$ gbs_navlinks_s

Kalmykova, Y., Sadagopan, M., \& Rosado, L. (2018). Circular economy - From review of theories and practices to development of implementation tools. Resources, Conservation and Recycling, 135, 190-201. https://doi.org/10.1016/j.resconrec.2017.10.034

Kim, W. C., \& Mauborgne, R. (2018). Océano Azul, Océano Rojo. Retrieved from https://books.google.com.mx/books?id=mVJLDwAAQBAJ\&dq=que+son+los+oceanos+rojos\&hl=es\&sour ce=gbs_navlinks_s

Laudal, T. (2011). Drivers and barriers of CSR and the size and internationalization of firms. Social Responsibility Journal, 7(2), 234-256. https://doi.org/10.1108/17471111111141512

Maldonado-Guzmán, G., Garza-Reyes, J. A., Pinzón-Castro, S. Y., \& Kumar, V. (2017). Barriers to innovation in service SMEs: Evidence from Mexico. Industrial Management and Data Systems, 117(8), 1669-1686. https://doi.org/10.1108/IMDS-08-2016-0339

McCormick, K., \& Kautto, N. (2013). The Bioeconomy in Europe: An Overview. Sustainability, 5(6), 2589-2608. https://doi.org/10.3390/su5062589

McWilliams, A., Parhankangas, A., Coupet, J., Welch, E., \& Barnum, D. T. (2016). Strategic Decision Making for the Triple Bottom Line. Business Strategy and the Environment, 25(3), 193-204. https://doi.org/10.1002/bse.1867

Mebratu, D. (1998). Sustainability and sustainable development: Historical and conceptual review. Environmental Impact Assessment Review, 18(6), 493-520. https://doi.org/10.1016/S0195-9255(98)00019-5

Melander, L. (2017). Achieving Sustainable Development by Collaborating in Green Product Innovation. Business Strategy and the Environment, 26(8), 1095-1109. https://doi.org/10.1002/bse.1970

Mention, A. L. (2011). Co-operation and co-opetition as open innovation practices in the service sector: Which influence on innovation novelty? Technovation, 31(1), 44-53. https://doi.org/10.1016/J.TECHNOVATION.2010.08.002

Mishra, D. R. (2017). Post-innovation CSR Performance and Firm Value. Journal of Business Ethics, 140(2), 285-306. https://doi.org/10.1007/s10551-015-2676-3

Moratis, L., \& Cochius, T. (2017). ISO 26000: The Business Guide to the New Standard on Social Responsibility. Taylor \& Francis. Retrieved from https://books.google.com.mx/books?id=2qk0DwAAQBAJ

Multaharju, S., Lintukangas, K., Hallikas, J., \& Kähkönen, A. K. (2017). Sustainability-related risk management in buying logistics services. The International Journal of Logistics Management, 28(4), 1351-1367. https://doi.org/10.1108/IJLM-05-2016-0134

Naranjo-Valencia, J. C., Jiménez-Jiménez, D., \& Sanz-Valle, R. (2011). Innovation or imitation? The role of organizational culture. Management Decision, 49(1), 55-72. https://doi.org/10.1108/00251741111094437

Nawaser, K., Khaksar, S. M. S., \& Shakhsian, F. (2011). Motivational and Legal Barriers of Entrepreneurship Development. International Journal of Business and Management, 6(11), 112-118. https://doi.org/10.5539/ijbm.v6n11p112

Näyhä, A. (2019). Finnish forest-based companies in transition to the circular bioeconomy - drivers, organizational resources and innovations. Forest Policy and Economics. https://doi.org/10.1016/j.forpol.2019.05.022

Nonaka, I., \& Toyama, R. (2003). The knowledge-creating theory revisited: knowledge creation as a synthesizing process. Knowledge Management Research \& Practice, 1(1), 2-10. https://doi.org/10.1057/palgrave.kmrp.8500001

OECD. (2017). Organisation for Economic Co-operation and Development. Small, medium, strong. Trends in 
SME performance and business conditions. Retrieved from https://books.google.es/books?id=OKpmtAEACAAJ\&dq=OECD,+development+economics+employee+in the+SMEs+2017\&hl=es\&sa=X\&ved=0ahUKEwjy1YTXov3aAhVE6xQKHYrTCM0Q6AEITzAF

Quarshie, A. M., Salmi, A., \& Leuschner, R. (2016). Sustainability and corporate social responsibility in supply chains: The state of research in supply chain management and business ethics journals. Journal of Purchasing and Supply Management, 22(2), 82-97. https://doi.org/10.1016/J.PURSUP.2015.11.001

Quinn, R. E., \& Rohrbaugh, J. (2011). A Spatial Model of Effectiveness Criteria : Towards a Competing Values Approach to Organizational Analysis. Management Science, 29(3), 363-377.

Rajeev, A., Pati, R. K., Padhi, S. S., \& Govindan, K. (2017). Evolution of sustainability in supply chain management: A literature review. Journal of Cleaner Production, 162, 299-314. https://doi.org/10.1016/J.JCLEPRO.2017.05.026

Ramani, S. V., \& Mukherjee, V. (2014). Can breakthrough innovations serve the poor (bop) and create reputational (CSR) value? Indian case studies. Technovation, 34(5-6), 295-305. https://doi.org/10.1016/j.technovation.2013.07.001

Revell, A., Stokes, D., \& Chen, H. (2009). Small businesses and the environment: turning over a new leaf? Business Strategy and the Environment, 19(5). https://doi.org/10.1002/bse.628

Ringle, C., Wende, S., \& Becker, J. (2017). SmartPLS—Statistical Software For Structural Equation Modeling. Retrieved from

https://scholar.google.es/scholar?hl=es\&as_sdt=0\%2C5\&q=Ringle\%2C+Wende $\% 2 \mathrm{C}+\% 26+\mathrm{Becker} \% 2 \mathrm{C}+2$ 017+SMARTPLS\&btnG=

Robinson, J. (2006). Navigating Social and Institutional Barriers to Markets: How Social Entrepreneurs Identify and Evaluate Opportunities. In J. Mair, J. Robinson, \& K. Hockerts (Eds.), Social Entrepreneurship (pp. 95-120). London: Palgrave Macmillan UK. https://doi.org/10.1057/9780230625655_7

Saunila, M. (2019). Innovation capability in SMEs: A systematic review of the literature. Journal of Innovation and Knowledge. https://doi.org/10.1016/j.jik.2019.11.002

Schuberth, F., Henseler, J., \& Dijkstra, T. K. (2018). Partial least squares path modeling using ordinal categorical indicators. Quality \& Quantity, 52(1), 9-35. https://doi.org/10.1007/s11135-016-0401-7

Scuotto, V., Del Giudice, M., Bresciani, S., \& Meissner, D. (2017). Knowledge-driven preferences in informal inbound open innovation modes. An explorative view on small to medium enterprises. Journal of Knowledge Management, 21(3), 640-655. https://doi.org/10.1108/JKM-10-2016-0465

Silvestre, B. S., \& Țîrcă, D. M. (2019, January 20). Innovations for sustainable development: Moving toward a sustainable future. Journal of Cleaner Production. Elsevier Ltd. https://doi.org/10.1016/j.jclepro.2018.09.244

Singh, S. K., Gupta, S., Busso, D., \& Kamboj, S. (2019). Top management knowledge value, knowledge sharing practices, open innovation and organizational performance. Journal of Business Research. https://doi.org/10.1016/j.jbusres.2019.04.040

Singh, S., Olugu, E. U., Musa, S. N., \& Mahat, A. B. (2018). Fuzzy-based sustainability evaluation method for manufacturing SMEs using balanced scorecard framework. Journal of Intelligent Manufacturing, 29(1), 1-18. https://doi.org/10.1007/s10845-015-1081-1

Sodhi, M. S., \& Tang, C. S. (2018). Corporate social sustainability in supply chains: a thematic analysis of the literature. International Journal of Production Research, 56(1-2), 882-901. https://doi.org/10.1080/00207543.2017.1388934

Spence, L. J. (2016). Small Business Social Responsibility. Business \& Society, 55(1), 23-55. https://doi.org/10.1177/0007650314523256

Teece, D. J. (2007). Explicating Dynamic Capabilities: The Nature and Microfoundations of (Sustainabile) Enterprise Performance. Strategic Management Journal, 298(13), 1319-1350.

Teece, D. J. (2010). Business models, business strategy and innovation. Long Range Planning, 43(2-3), 172-194. https://doi.org/10.1016/j.lrp.2009.07.003

Teece, D. J. (2016). Dynamic capabilities and entrepreneurial management in large organizations: Toward a theory of the (entrepreneurial) firm. European Economic Review, 86, 202-216. 
https://doi.org/10.1016/J.EUROECOREV.2015.11.006

Tucci, C. L., Chesbrough, H., Piller, F., \& West, J. (2016). When do firms undertake open, collaborative activities? Introduction to the special section on open innovation and open business models. Industrial and Corporate Change, 25(2), 283-288. https://doi.org/10.1093/icc/dtw002

Urbach, N., \& Ahlemann, F. (2010). Structural Equation Modeling in Information Systems Research Using Partial Least Squares. Journal of Cleaner Productionurnal of Information Technology Theory and Application, 11(2), 5-40. https://doi.org/10.1037/0021-9010.90.4.710

Usman, M., \& Vanhaverbeke, W. (2017). How start-ups successfully organize and manage open innovation with large companies. European Journal of Innovation Management, 20(1), 171-186. https://doi.org/10.1108/EJIM-07-2016-0066

Valdez-Juárez, L. ., Solano-Rodríguez, O. J., \& Philippe-Martin, D. (2018). Modes of learning and profitability in Colombian and Mexican SMEs. The Journal of High Technology Management Research, 29(2), 193-203. https://doi.org/10.1016/J.HITECH.2018.09.007

Valdez-Juárez, L., Gallardo-Vázquez, D., Ramos-Escobar, E., Valdez-Juárez, L. E., Gallardo-Vázquez, D., \& Ramos-Escobar, E. A. (2018). CSR and the Supply Chain: Effects on the Results of SMEs. Sustainability, 10(7), 2356. https://doi.org/10.3390/su10072356

van Oorschot, J. A. W. H., Hofman, E., \& Halman, J. I. M. (2018). A bibliometric review of the innovation adoption literature. Technological Forecasting and Social Change, 134, 1-21. https://doi.org/10.1016/j.techfore.2018.04.032

Vitolla, F., Rubino, M., \& Garzoni, A. (2016). Integrated corporate social responsibility: Driving factors and means of integration - a multiple case study analysis. Journal of Management Development, 35(10), 1323-1343. https://doi.org/10.1108/JMD-08-2015-0113

Vitolla, F., Rubino, M., \& Garzoni, A. (2017). The integration of CSR into strategic management: a dynamic approach based on social management philosophy. Corporate Governance (Bingley), 17(1), 89-116. https://doi.org/10.1108/CG-03-2016-0064

West, J., Salter, A., Vanhaverbeke, W., \& Chesbrough, H. (2014). Open innovation: The next decade. Research Policy. Elsevier B.V. https://doi.org/10.1016/j.respol.2014.03.001

Wikhamn, B. R., \& Styhre, A. (2017). Open Innovation as a Facilitator for Corporate Exploration. International Journal of Innovation Management, 21(06), 1750042. https://doi.org/10.1142/S1363919617500426

Wolf, J. (2014). The Relationship Between Sustainable Supply Chain Management, Stakeholder Pressure and Corporate Sustainability Performance. Journal of Business Ethics, 119(3), 317-328. https://doi.org/10.1007/s10551-012-1603-0

Zhao, Z., Meng, F., He, Y., \& Gu, Z. (2019). The Influence of Corporate Social Responsibility on Competitive Advantage with Multiple Mediations from Social Capital and Dynamic Capabilities. Sustainability, 11(1), 218. https://doi.org/10.3390/su11010218

\section{Copyrights}

Copyright for this article is retained by the author(s), with first publication rights granted to the journal.

This is an open-access article distributed under the terms and conditions of the Creative Commons Attribution license (http://creativecommons.org/licenses/by/4.0/). 